\title{
Pseudoelastic nature of pterygium
}

\author{
M. W. ANSARI, A. H. S. RAHI, AND B. R. SHUKLA \\ A.M.U. Institute of Ophthalmology, Aligarh, India
}

Elastotic degeneration in cases of pterygium, as in pinguecula, is characterized by the appearance of vermiform, coiled, and knotty fibres which take up elastic stain, but these so-called elastic fibres appear to differ from natural elastic tissue. There are certain skin diseases in which an apparent increase in elastic fibres is seen (Tunbridge, Tattersall, Hall, Astbury, and Reed, 1952). Gillman, Penn, Bronks, and Roux (1954) called these fibres "elastotically degenerated" because they can only mimic the staining character of true elastic tissue. They remain unaffected by the pancreatic elastase, an enzyme discovered by Baló and Banga (1949) which is supposed to have a specific action on such tissue (Hall, Reed, and Tunbridge, 1952).

It was thought in the past that in pinguecula there was an increase in the elastic fibres normally present in the bulbar conjunctiva, but Cogan, Kuwabara, and Howard (1959) proved by the use of pancreatic elastase that they were non-elastic in nature. Vass and Tapaszto (1964) extended this study to pterygium but did not reach a firm conclusion. We therefore undertook the present investigation to find out the precise changes in pterygium tissue deep to the conjunctiva with special reference to the elastic fibres.

\section{Material and methods}

The material was obtained from patients who attended the Gandhi Eye Hospital, Aligarh, in 1967 and 1968. Pterygia removed from 45 patients were fixed, blocked, and sectioned, and stained with haematoxylin and eosin, van Gieson's stain, and Verhoeff's stain. Three showed typical "elastotic degeneration" and these tissues were subjected to enzyme digestion for periods of 1, 3, 6, 12, and 24 hours. The enzyme pancreatic elastase of $16 \mathrm{U} / \mathrm{mg}$. activity* was used in $\mathrm{I}: 2000$ dilution at $37^{\circ} \mathrm{C}$ (Sachar, Winter, Sicher, and Frankel, 1955). The diluent was $0 \cdot 1$ molar bicarbonate buffer of $\mathrm{pH} 8 \cdot 6$.

Microsections of goat aorta, which contains a large amount of elastic tissue, were used as controls.

\section{Observations}

(I) So-called elastotic degeneration (Fig. I, overleaf) was seen in only three pterygia out of 45 cases (6 per cent.).

(2) The pterygium fibres showed no morphological change except for a little fading of the elastic stain (Fig. 2, overleaf). 


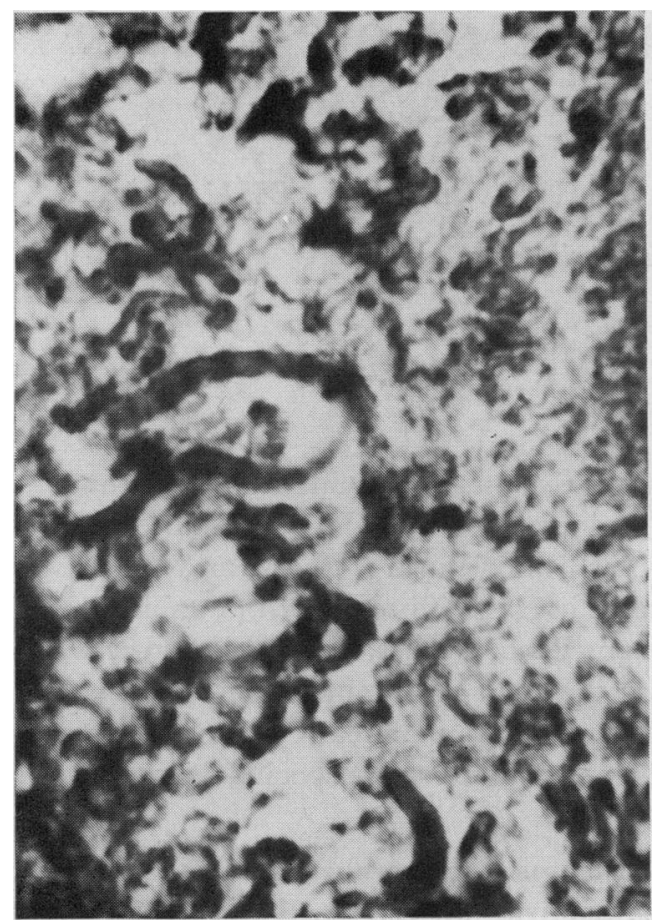

FIG. I Photomicrograph of stroma of pterygium, showing elastotically degenerated collagen before enzymatic digestion, and vermiform degenerate fibres. $\times 800$

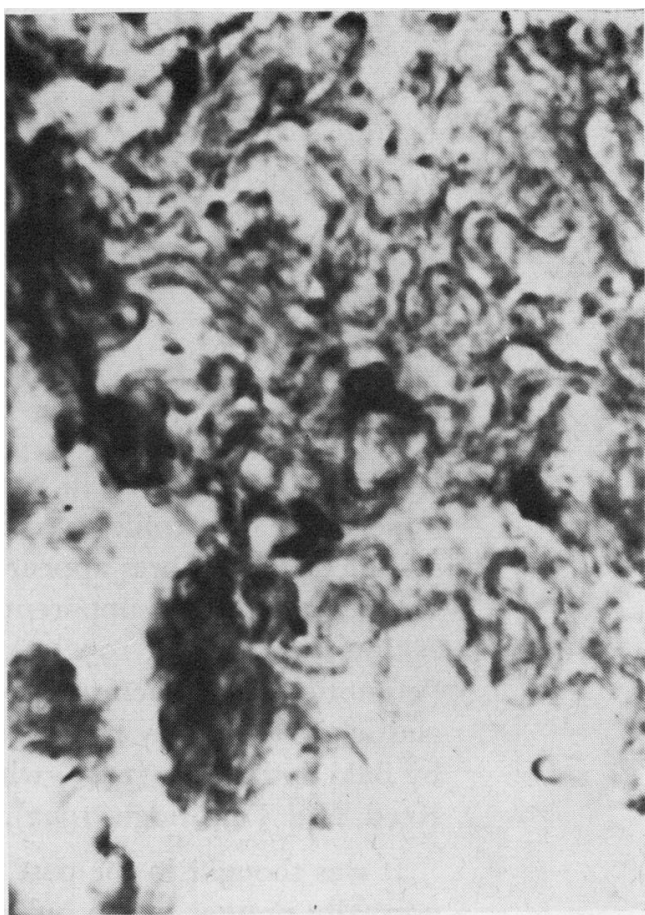

FIG. 2 Stroma of pterygium, after 24 hours' enzymatic digestion by elastase, showing elastotically degenerated collagen, wtih some fading of Verhoeff's stain. The vermiform fibres show no morphological change. $\times 45^{\circ}$

(3) Elastic fibres of control goat aorta showed gradual splitting, granulation, and ultimately lysis under the influence of elastase (Figs 3 and 4 ).

\section{Discussion}

The routine staining reaction does not differentiate reliably between true elastic tissue and elastotically degenerated fibres (Gillman and others, I954). Cogan and others (I959) therefore utilized the action of pancreatic elastase on the stromal fibres of pinguecula to determine their precise nature. Using as a control the elastic tissue of hog aorta, which contains much elastic tissue, they demonstrated that the controversial stromal fibres in a pingueculum did not seem to be real elastic tissue because they were only partially digested by elastase. They used the term "pseudoelastic tissue" for the fibres found in pinguecula.

The presence of similar fibres in the stroma of degenerating pterygium has been observed by all workers; Sugar (1949) and Sugar and Kobernick (1959) used the term "hyperelastosis" (an actual increase in elastic tissue), Gerundo (I 95 I) wrote of "undulating fibres" and "an amorphous acellular mass with hyalinization" in various stages of a pterygium. Kamel (1954) could not go beyond "elastic tissue-like degeneration". Vass and Tapeszto ( 1964 ), in a histoenzymatic study of pancreatic elastase, concluded that the fibres were not true elastic tissue because they were only partially digested by elastase, and suggested that they were some form of altered collagen. These authors had used tissue from the human conjunctival fornix as a control. Duke-Elder ( 1965 ) called the process "elastotic degenera- 


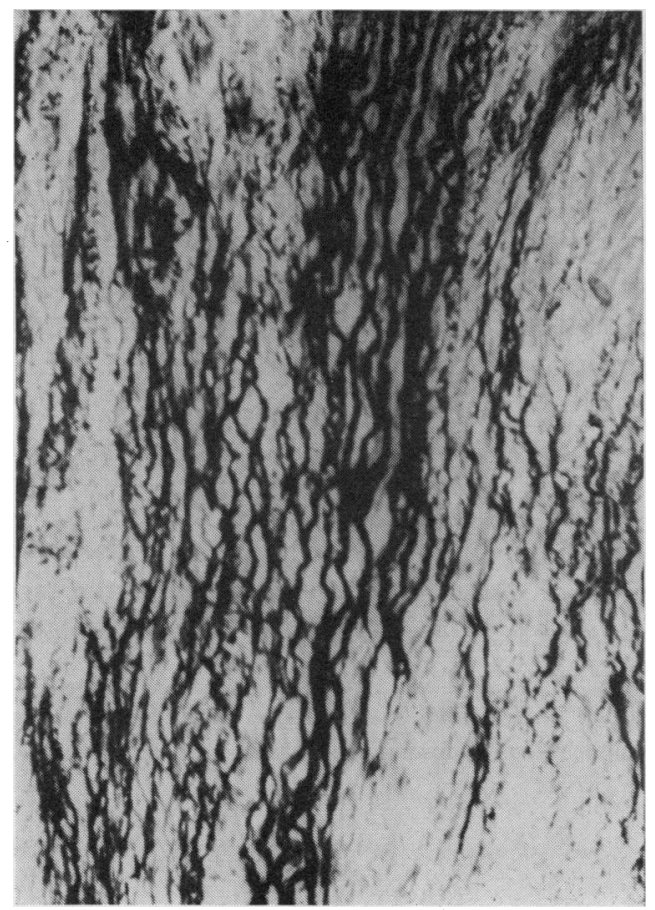

FIG. 3 Photomicrograph of tissue from goat aorta, showing elastic tissue (black) before enzymatic digestion. $\times 45^{\circ}$

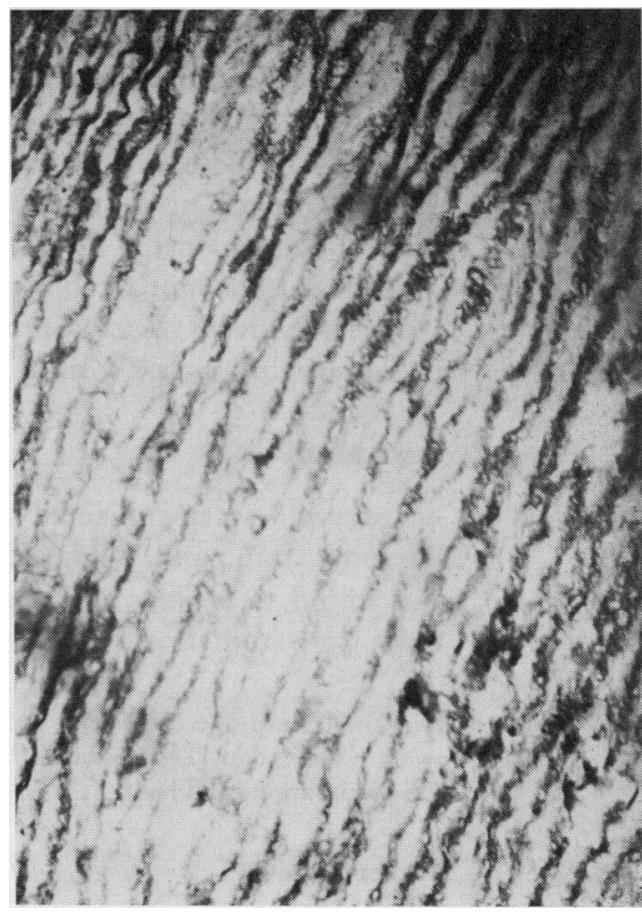

FIG. 4 Tissue from goat aorta, after 24 hours' enzymatic digestion, showing swelling, granulation, and eroded appearance of elastic fibres. $\times 450$

tion" and attempted to close the controversy, but tradition dies hard. Cameron (I965) again mentioned "many-curled elastic fibres" and "wavy collagen fibres" replacing the superficial corneal lamellae, and wrote that "limbally the stroma of a pterygium showed a picture of senile elastosis". In a report on the histopathology of pterygium, Takebayashi (I 966$)$ referred to "increased elastic fibres".

In our series of 45 cases, the most important changes seemed to occur in the conjunctival stroma; 75 per cent. showed a hyperplasia of collagen, subconjunctival hyperaemia, and neovascularization. The hyperplasic collagen fibres showed fragmentation and a little coiling which we regard as a predegenerative stage. Clear-cut hyaline degeneration was seen in four cases and elastotic degeneration only in three in which the pterygium was of long duration. This late development of degeneration is an important feature distinguishing pterygia from pinguecula, in which the degenerative lesion is present from the beginning.

Our studies indicate that there is no hyperelastosis as was suggested by Sugar (1949) and Sugar and Kobernick (1959). The so-called elastic fibres are a degenerate form of collagen which takes up a misleading elastic stain. We therefore suggest the use of the term "pseudoelastic tissue" (Cogan and others, 1959). Moreover, judging from our material, this degeneration is not so common in pterygium as the literature would lead one to suppose.

The chemical basis of this altered staining reaction of degenerating collagen fibres is not known, though it has been shown that collagen and elastic fibres differ in the nature and amount of their amino acid content (Pearse, I960). It is known that long-standing 
cultures of Gram-positive organisms become in time Gram-negative, probably through some change in the magnesium-ribonucleate content. This established phenomenon suggests that, as the collagen ages or degenerates in pathological conditions, it loses its natural staining character so that it can take up an elastic tissue stain. Since the staining depends mainly upon the surface chemicals, a degenerative product simulating one of the normal constituents of elastic tissue may perhaps be deposited in the area of degeneration. This might account for our observation that the enzyme elastase which could digest the true elastic tissue of aorta produced no morphological change in the area of degeneration in a pterygium apart from a little fading of the elastic stain.

\section{Summary}

45 pterygia were subjected to histopathological study by haematoxylin and eosin, von Gieson's stain, and Verhoeff's stain. The incidence of so-called elastotic degeneration was found to be low. The controversial convoluted fibres found in the stroma in three cases were studied with pancreatic elastase and were found to be "pseudoelastic" in nature.

Our thanks are due to Messrs. Calbiochem of Switzerland who supplied pancreatic elastase for this study, and to Mr. Khan, Technician in the Histopathology Department of the AMU Institute, for his help with the preparation of slides.

\section{References}

baló, J., and banga, 1. (1949) Schweiz. Z. Path. Bact., 12, $35^{\circ}$

CAMERON, M. E. (1965) "Pterygium throughout the World". Thomas, Springfield, Ill. Cogan, D. G., kUWABARA, T., and howard, J. (1959) A.M.A. Arch. Ophthal., 6r, 388 DUKE-ELDER, S. (1965) "System of Ophthalmology", vol. 8, part I, p. 573. Kimpton, London GILlMAN, T., PENN J., BRonks, D., and Roux, M. (1954) Nature (Lond.), 174, 789

GERUNDo, M. (195I) Amer. F. Ophthal., 34, 85I

HALL, D. A., REED, R., and TUNBRIDGe, R. E. (1952) Nature (Lond.), 170, 264

KAMEL, s. (1954) Amer. F. Ophthal., 38, 682

PEARSE, A. G. E. (1960) "Histochemistry-Theoretical and Applied", and ed., p. 625. Churchill, London

SaChar, L. A., Winter, K. K., sicher, N., and frankel, s. (1955) Proc. Soc. exp. Biol. (N.Y.), 90, 323 SUGAR, H. s. (1949) Amer. F. Ophthal., 32, 912

- and KOBERNICK, s. (1959) Ibid., 47, 34I

TAKebayashi, м. (1966) Acta Soc. ophthal.jap., 70, 457 (quoted in Abstracts in Amer. F. Ophthal., 64, $345(1967))$

TUNBRIDGE, R. E., TATTERSALl, R. N., HALl, D. A., ASTBURY, w. T., and REED, R. (1952) Clin. Sci., I1, 315

vass, z., and TAPASZTo, I. (1964) Acta ophthal. (Kbh.), 42, 849 